\title{
NONVIOLENCE LOVES FREEDOM
}

\author{
Guntis Šmidchens. The Power of Song: Nonviolent \\ National Culture in the Baltic Singing Revolution. New \\ Directions in Scandinavian Studies. Seattle \& London: \\ University of Washington Press; Copenhagen: Museum \\ Tusculanum Press, 2014. 416 pp.
}

This in-depth monograph by Guntis Šmidchens analyses the Singing Revolution, with an emphasis on the role of singing in violent resistance.The process in the Baltic states in the late 1980s was unusual as, first, three small countries managed to secede from the empire and, second, the independence movement proceeded as a sequence of nonviolent music events, such as song festivals, folklore festivals, but also as a singing human wall confronting military forces.

Although the solution was achieved not only by means of singing but also due to relevant political procedures and a favourable historical moment, this happy-ending narrative offers a significant experience to the humanity.

Social topics are associated with ideology, which in turn depends on people's groupbelonging and viewpoints. The author of the book, Guntis Šmidchens, from Washington University in Seattle, has been influenced both by the international research tradition and his ethnic Latvian origin. Unlike the earlier treatments of the Singing Revolution (e.g. Ruutsoo 2002a, 2002b; Rinne 2008), Šmidchens focuses on the study of music-related issues: Why did the fight for the independence of the Baltic states come to be called the Singing Revolution? What was sung and what was the role of singing in political success (p. 5)? Whether and how is it possible to combine the principles of nonviolence in the fight for national statehood (p. 6)? In what way did the power of song actually work? Here I would like to mention that I am Estonian folklorist and ethnomusicologist myself and therefore I belong - temporally, spatially, and by my convictions - to the group depicted in the book, and I acknowledge that my writing is influenced both by the subjective group identity and scientific viewpoints striving for objectivity.

The book has found its place among the researches into the past decade, which deal with the role of music in a nation's history, such as The Music of European Nationalism: Cultural Identity and Modern History (Bohlman 2004), Laulava vallankumous (Kurkela \& Rantanen 2008), The Intersection of Ethnic Nationalism and People Power Tactics in the Baltic States, 1987-91 (Beissinger 2009), History in Mighty Sounds: Musical Constructions of German National Identity, 1848-1914 (Eichner 2012), and Laulun mahti ja sivistynyt kansalainen (Rantanen 2013). To a certain extent, these researches on 
relatively close topics and even with rather similar titles could well have been initiated by the Singing Revolution.

In the discourse of nationalism, the author's viewpoint represents nationality and its culture-valuing direction, as well as demonstrates the democratic nature of a small nation's independence movement in a situation where native-language culture and natural habitat are endangered. Another direction that is brought to the fore, for example, in Philip Bohlman's research titled The Music of European Nationalism (2004), regards nationalism as a source of threat, which also casts a shadow over nationalistic music. Šmidchens also creates a mental connection between these two books by his own interpretations of several phenomena discussed by Bohlman, such as Herder's heritage, national anthems, the connection of folkloric presentations with the nation state, etc.

Guntis Šmidchens places the theoretical and historical starting point of his research in the period of activity of Johann Gottfried Herder (chapter 2), one of the main founders of folkloristics and appreciator of different national cultures. The highlight of this period was the publication of the folk song collection, Volkslieder (1778-79), mainly known under the title of its reprint, Stimmen der Völker in Liedern (1807). The author mentions Herder and his folk song collection as an example to be followed, as "Herder also pioneered ethnographic methods that remain useful today. He aimed to document humanity as experienced by people 'from inside', in their own words" (p. 25), and the researcher's own goal is "to interpret meanings as Balts themselves may have imagined them when they sang, or, following the lead of Anthony David Smith, to enter the participants' 'inner world"' (Smith 2009: 4). As such, this research belongs mainly in the sphere of ethnomusicology, according to the methodology of which music is analysed in its historic context, on the basis of credible material, considering the viewpoint of those inside and observing the relationships between music and society.

Šmidchens also follows the example of another aspect of Herder's activity - to translate, comment on, and publish folksongs so that their influence would reach from their creators to the readers: "Songs have an effect on people who sing them. [---] Such is also the goal of this book" (p. 25). Including Herder in his work as alter ego is a tribute to the German philosopher; although the latter's works were not research, he attempted to highlight the common human part in different nations, value the preservation and development of different cultures, mother tongue, and living in peace and love rather than fighting.

The idea to influence readers through songs, chosen and commented by the author, builds a kind of contradiction with the intention of just communicating the insiders' viewpoint. While the author's aim is to influence people through lyrics, his writing is not pure science, but it also subjectively transmits the author's ideas.

Even if we do not to deny Herder's impact on history, his importance in shaping the Balts' nonviolence and singing practice is shown as disproportionally great, for example: "The historical roots of the Baltic Singing Revolution reach back more than two centuries, to Johann Gottfried Herder's discovery of folk songs", or: "When Herder discovered and celebrated the local folk poetry, he also planted hardy seeds of nonviolence in the field of Baltic nation building” (p. 308). The line between Herder's interest in folklore and the evolution of nonviolent joint singing of the Balts is somewhat disrupted both in history and in Šmidchens' text, due to the fact that the older folksongs that Herder had been enthused about faded away during the period of national awakening, and choral 
singing, one of the pillars of the Singing Revolution, was based on the polyphonic song of German origin. The role of the folksong was more significant in Latvian and Lithuanian Singing Revolutions than in Estonia, because the former two feature a comparatively smaller gap between the older folksong and the more recent singing culture. During the Soviet period, the Estonian archaic folk song (regilaul) with its mysterious dialect texts was well suited to carry a hidden meaning; yet, as Šmidchens admits, it did not wield significant influence in the days of the Singing Revolution. The same contradiction in the interpretation of Estonian music history has been highlighted also by Estonian literary critic Rein Veidemann: although we would willingly imagine that the Singing Revolution emerged on the basis of Estonian folksongs, the older folksong actually played no special role in these revolutionary events (Veidemann 2008). It is mindful of Šmidchens to use for the old Estonian folk song the native term regilaul, instead of the Finnish term runolaul. If we juxtapose Herder's, Šmidchens' and Bohlman's works, the subjective role of each author in interpreting research material becomes more evident. Šmidchens himself has demonstrated quite well, on the basis of the first print of Herder's collection (1778-1779), its reprint (1807), and their compilation stories how the author, by means of the selection of songs, composition of the book, and comments reveals his own ideas. Herder saw folksongs "in a new frame of universal humanity, as a fundamental expression of human love" (p. 28), and the purpose of their publishing could have been, by his words, that "humans would be friends of humans, and no nation on earth sharpens its swords anymore" (p. 45). Herder's personal life - his love story and abstaining from military service - certainly influenced the thematic division of songs and his comments in the first edition (p. 26). The reprint, however, was compiled by his wife and the editor, who, unlike Herder's idea to classify the songs according to the content, did it by nations. As the reprint also excluded a summary intended by Herder, Universal Voice of Humankind: Moral Songs. Songs (Gesänge) for the Folk, his crossnational idea was not highlighted (p. 45).

However, as the first edition soon became a rarity, it was the reprint that was usually read; so, "whereas Herder had envisioned a single, universal voice (eine Stimme) of humankind expressed in the songs of many nations, the editors produced a book of many voices (Stimmen)" (p. 46). In the above, I can see another, indirect dialogue with Bohlman, who states that "he [Herder] devoted two books to the potential of song to articulate national diversity" (Bohlman 2004: 42). ${ }^{1}$ So the posterity somewhat failed to discern Herder's own ideas.

The structure of the book considers the insider's viewpoint: in the opening chapter representatives of the Balts speak, which is followed by the descriptions of the evolution of national identities, valuation of folksongs, and development of the national choral song (chapters 2 and 3), the more belligerent historic events (chapter 4), the persistence of opposition during the Soviet period (chapter 5), as well as the convergence of different music trends in the events of the Singing Revolution (chapters 6-8).

The author inspires great respect for his comprehensive knowledge of the Baltic nations, which enables to depict them as part of a common cultural space. Šmidchens is also able to explain some circumstances not so easily understood by people with a different cultural background. First, he shows the evolution of national processes in the Baltic countries, from strengthening the identity of an ethnic minority and claiming the right for self-determination to becoming a nation, which meant independent 
development, and not aggression against other nations; citing Beissinger: "nonviolence and passionate ethnic identity need not be incompatible" (p. 319).

The author's good knowledge of local conditions is also revealed in his ability to shed light on the Soviet-time two-layered culture, which reflected the inconsistency between the mass culture shaping Soviet identity and the preservation of national idiosyncrasies. Soviet culture featured an official side, seemingly supporting nationality yet actually levelling it, and the hidden 'true' side corresponding to the nation's mentality. This discrepancy was also manifest in folkloric performances (which intuitively could be regarded as an unequivocally national activity): on the one hand, a stylised stage performance in national form, filled with socialist content, and, on the other, so-called authentic 'true' presentation reproducing the past heritage. Bohlman has in detail discussed the changing of national culture into state-controlled culture, which brings about the levelling of regional idiosyncrasy; yet, he has not distinctly detached the phenomena of official cultural policy, such as Hungarian military folklore ensemble, from folk culture (Bohlman 2004: 98).

Those who do not know anything about the lack of freedom of speech fail to perceive the subtle difference between real enthusiasm in conformity with ideology, its obedient or naïve imitation, and derisive 'exaggerated enthusiasm'. Šmidchens presents an example of a situation from the opening concert of a Latvian song festival in 1895, in which the singers' exaggeration with political correctness changed the meaning of the text and granted them mental victory. The metropolitan of the Orthodox Church, a representative of Russification, was supposed to take the floor there, yet the singers, yielding to the urgent requests of the audience, repeated the Russian anthem as long as the metropolitan was forced to leave without saying a word (p. 101).

The author has been influenced by Havel's essay, Power of the Powerless (1978), on the example of which he calls the real feelings manifested in singing "living within the truth"; the heading of his book, The Power of Song, as well as headings of four chapters out of eight also include allusions to Havel's expressions.

The consideration of the insider's viewpoint in Šmidchens' book is revealed in the usage of the word 'nationalism' (see also Ojamaa \& Labi 2007). In English the word nationalism (< nation 'nationality', 'people'; also 'state') could present a judgement more clearly indicated in the adjectives of the same root - national (neutral or positive), and nationalist(ic) (negative); the same applies to Latvian and Lithuanian root tauta.

Ahti Mänd (1995) has mentioned that the meaning of the word nationalism also depends on political context: in general it endeavours to preserve national belonging, yet great powers and their majorities, whose political independence is self-evident, may regard their minorities' nationalism as a threat to the unity of the state (see also Madisson \& Maddisoo 1935-1936). Estonians are a small nation, and therefore the word 'nationalism' initially lacked a negative shade of meaning; it is a more recent addition from the position of a great power, to discredit the rather positive message of nationalism directed towards the preservation of identity (Mänd 1995).

The English-language tradition, as it is present in Bohlman's book, uses both the concepts, national and nationalist; yet the difference between these two is unclear in places; also the concept nation denotes ethnos, nation, or state (Ojamaa \& Labi 2007). Due to these overlappings, the concept nationalist(ic) casts a kind of shadow over national/ethnic cultures that try to preserve their idiosyncracy. Yet, Šmidchens in his 
text always uses the word national in neutral meaning; the concept nationalist occurs only in a few places, to translate the derogatory labels applied to the representatives of national cultures by the Soviet Union (p. 292).

Šmidchens' multi-layered, carefully composed work reveals the impact of romantic dualist approach to society; for instance, Herder's differentiation between belligerent and peaceful nations (chapter 4 is titled Songs of Warrior Nations). The author's contemplations reveal opposites, such as violent - nonviolent, power - spirit, soviet - national, collective - individual, etc., and indirectly also bad - good. This division into two features knots of opposites, seemingly inconsistent combinations, such as "power of the powerless" (see Havel 1978) or the "singing revolution" itself. Contrasting is also included in the seemingly neutral heading of the introduction, Three Nonviolent National Cultures, considering the problem mentioned by the author - the question "whether it is possible to reconcile nonviolent principles with a pursuit of nationalist power" (p. 6). The headings including oxymorons point to the optimistic idea of the book that it is possible to join the seemingly incompatible, for instance, nonviolence and power.

Although Šmidchens aims to show, above all, the positive aspects of singing and mass movement, he cannot deny that music has also been part of less humane systems as well as a way of combat; for instance, martial music. Chapter 4, titled Songs of Warrior Nations, is dedicated to military activity and songs, yet the author regards them as non-dominant and places them - hopefully justifiably - into the past:

More than a century of war songs were deeply embedded in the national cultures as deeply as the peaceful songs presented in the preceding chapters. War has long played an important role in the formation of ethnic identity, and it is a common theme in the discourse of nation building. (p. 108)

However, the chapter is only loosely connected with the dominant ideology in the book and after reading it you feel as if these peoples have proceeded from one victory to another only by singing.

The book presents imposing examples of the victories the spirit has won over the power, yet dwells less on the fact that music could be a feeble weapon in the fight for lofty ideals, and that throughout history music has also been used to make human masses act for less valuable causes. The author has left aside more violent and less victorious periods in the recent history of the Baltic countries, such as the victory in the War of Independence (1918-1920) and the nonviolent surrender to the Soviet Union in 1940. Therefore it is hard to establish in which cases the power of song works.

However, several of the phenomena discussed in the book cannot be categorised as opposites; for instance, nations cannot be divided into militant and loving, the former having many war songs and the latter many love songs - any of them can have plenty of both. Other cultural phenomena also feature uniting of two opposite sides; for instance, in Norse mythology Freya is a goddess of both war and love.

Nor can we claim that Soviet identity was, above all, collective and suppressing the personality, whereas national identity was individual and freeing the personality - the prerequisite for the Singing Revolution was a strong collective national identity. In this respect the description of the Soviet-time music education as a negative example 
of suppressing the personality is not convincing: choral singing requires synchronised joint singing, understandable words, and no one's voice standing out (p. 324).

The real influence of music is revealed through the analytical description of the Singing Revolution. Different music styles carried contradictory ideas through the occupation period and became part of revolutionary events, which in turn exerted an impact on creating new music. Choral singing fulfilled the needs of mass movement as many singers knew the common patriotic repertoire. Due to acoustic amplifiers rock music was heard from afar and reacted quickly to various circumstances. Simple-style joint singing united the nation and acquired new meanings in new situations; folklore enabled people to identify themselves with former generations and sing in small groups.

Resistance appears to have taken place not only by singing but also by the power of crowd, which formed a physical and moral barrier. The latter emanates from the fact that, according to human ethics, no-one attacks an armless, peaceful crowd. Šmidchens says:

In 1991, individual courage, multiplied by the thousands, motivated thousands of people standing on the barricades in Lithuania, Latvia, and Estonia, unarmed, each of them preparing to receive their Soviet adversary's violence, and hoping to awaken their attacker's conscience. (p. 325, emphasis added)

Songs express the message of the fight to both sides, render meaning to agency, and convince the adversary that no easy victory can be expected.

Also songs help people to perceive mutual support and responsibility:

Nonviolent revolutions rest on the shoulders of disciplined, unified masses of people. They depend upon each individual's active participation, and on an awareness of importance of one's own voice among many others. (p. 206)

The author discusses the difference between the usage of songs as part of violent and nonviolent fight. One of the features of nonviolence was hidden in the lyrics: they focused on the construction and consolidation of national identity and ideology rather than destruction of the opponent (p. 251). However, he admits that this particular feature does not sufficiently define nonviolent singing, because the repertoire also included songs with belligerent content to encourage bravery. Also the author mentions that although the leaders of the movement called for keeping the peace, they were ready to fight (p. 315). So the line between nonviolence and violence was fragile and the headings of the introduction and conclusion, Three Nonviolent National Cultures and Nonviolent National Singing Traditions, partly remain in the sphere of national myth. Šmidchens elaborates on Baltic national myths, complementing the well-known saying "Estonians/ Latvians/Lithuanians are a singing nation" with the concept of nonviolence (chapter 3 is titled Three Singing Nations and Their Songs). However, nonviolent fight by means of music is inherent not only in the Balts; for instance, American Indians have also offered resistance with music and dance (Brown 1975 [1970]). Germans and Finns have also been called singing nations in connection with peaceful national movements. Substantial parallels with the book under discussion can also been found in Barbara Eichner's study (2012) on the role of music in the development of the German nation, which includes a subchapter titled German Song Our Weapon: The Male Choir Movement as a Forum for Political Communication, which refers to the power of song. In Germany the formation 
of a civil society was associated with singing, based on a somewhat religious idea that singing makes people better: "Throughout the nineteenth century the male choir movement was one of the main catalysts of the belief in the improving and educating powers of art, especially music" (ibid.: 182). Male choir singing in the mid-19th century was a peaceful movement related to the peculiar German-style development, which specified that nationalism was supposed to remain friendly and liberal; organising public events by making use of the uniting power of song was called Gefühlspolitik (ibid.: 190, 192).

Ideas of the Baltic peoples' power of song also date back to the 19th century; to confirm this, Šmidchens cites Latvian poet Auseklis, who, after he had seen a song contest Song Wars in 1873, wrote:

The nation in whose breast there flow and thunder waves of immortal song spirit, akin to the crashing waves of the sea, lives in golden happiness. That nation does not stain steel swords and spears with the precious blood of people. Peace is its stately, proud flag; a shield of songs which repels the spear. (pp. 99-100)

Valuing nonviolence as a positive feature is meaningful from the point of view of ideological developments, as in the 19th century belligerence constituted part of national pride, and a common regretful comment about Estonians was that this small nation did not have great, i.e. belligerent, history.

Speaking about people's ability to resist by singing creates an image of a special spiritual power, because fighting a strong enemy with music is associated with the supernatural - this faculty has been attributed to gods and exceptional people, such as Orpheus or Väinämöinen.

These myths are not directly confirmed by history; for instance, the first record of Estonians' music dates back to a plundering raid to the Danes in 1172, when Estonians, before the battle, "bacchantium more cantu choreisque laetitiam simulabant, Danis tristem silentio noctem ducentibus" (like bacchants, expressed their joy by song and dance, while the Danes spent a dismal night in silence) (Saxo: 15-16, see Laugaste 1963). However, there is no proof about Herder having substantially influenced the shaping of nonviolent identity:

Regardless of whether Estonians, Latvians, and Lithuanians were or weren't nonviolent nations before Herder, what he wrote about them left an imprint on later interpretations of current national spirit and future national missions. (p. 46)

The national myth presents the emotional truth: Šmidchens creates an impression as if nonviolence and singing are inherent, above all, in the Balts' national cultures.

Šmidchens builds on the foundation of historical truth, gathered bit by bit, a philosophy of nonviolent peoples and their intrinsic musical way of acting, which, despite certain idealism, makes reading especially enjoyable. The book is carried by hope, on the borderline of reality and social utopia, to change the world with the help of spiritual power through song, and one of its manifestations is the very book.

One of the fields of study is songs intertwined with historical events: the book presents 112 key texts, worthy of inclusion in the discourse on national identity, selected by the Balts themselves (p. 4). I dare to confirm the competence in the selection and interpretation as concerns Estonia. However, the song material published on the basis 
of Volkslieder (Herder 1778-1779) and translated repeatedly would have needed a textcritical approach and clarity in the author's viewpoints as to Herder's refined comments. When studying source materials (Meyer 1896), I have found translation errors that hinder understanding of the songs. Estonian folklorist Ülo Tedre has published an article, Eesti rahvalauludest K. Marxi albumis (Estonian Folksongs in K. Marx's Album) (Tedre 1961), on the two Estonian folksongs in Herder's collection, in which he proves that one of them is of Livonian origin.

The published Estonian folksongs represented archaic culture and did not directly express categories (or their absence) essential for Herder - love and belligerence: the suitability of Venna sõjalugu (The Brother's War Tale) as an example of Estonians' love of peace is rather questionable (see, e.g., Penttinen 1947; Tedre 1974: 233; Oinas 1994); wedding songs and slavery song (according to Estonian original text), however, do not directly express lack of love due to serfdom or hard life as the spouse's slave, as Herder's and Šmidchens' comments suggest (pp. 36-40). Šmidchens admits that Herder's interpretation helps him to understand the songs according to his views: "Herder wanted songs that would exemplify oral poetry's power. The new Estonian and Latvian songs did that, and more, when Herder added rhetorical comments about social justice" (p. 37). Furthermore, if we view belligerence as a search for violent solutions, Estonians' enemy was the local foreign nobility, and war songs were replaced by songs against the oppressors. Estonians' peaceful mind was necessarily not their intrinsic feature or Herder's accomplishment, but inevitable silent resistance conditioned by serfdom.

In his study, Guntis Šmidchens has emphasised the beauty of history, in places choosing more suitable facts to achieve a more comprehensive picture. The book full of facts juxtaposes interesting sources; the text is fascinating, emotional, and compositionally complete. The ideological image of powerfully singing small nations is fragile, and its joins are clearly visible, yet I would not like to damage with my criticism this beautiful construct, presenting history from a hopeful point of view. More often than not, research is based on an idea to be substantiated - and it is remarkable even if it results in the exploration of only one side of a phenomenon. In his book Guntis Šmidchens dwells upon outstanding events in history and therewith erects a worthy written monument to the Singing Revolution.

Taive Särg

\section{Note}

1 Bohlman mistakenly refers to the books Volkslieder and Stimmen der Völker in Liedern with the same years (1778-1779); actually the latter was published in 1807 (Bohlman 2004: 42, 381). 


\section{References}

Beissinger, Mark R. 2009. The Intersection of Ethnic Nationalism and People Power Tactics in the Baltic States, 1987-91. In: Adam Roberts \& Timothy Garton Ash (eds.) Civil Resistance and Power Politics: the Experience of Non-Violent Action from Gandhi to the Present. New York: Oxford University Press, pp. 231-46.

Bohlman, Philip V. 2004. The Music of European Nationalism: Cultural Identity and Modern History. World Music Handbooks: The Musics of Europe. Santa Barbara \& Denver \& Oxford: ABC CLIO.

Brown, Dee 1975 [1970]. Bury My Heart at Wounded Knee: An Indian History of the American West. New York: Bantam Books.

Eichner, Barbara 2012. History in Mighty Sounds: Musical Constructions of German National Identity, 1848-1914. Music in Society and Culture, Vol. 1. Woodbridge: The Boydell Press.

Havel, Václav 1978. The Power of the Powerless. Available at http://vaclavhavel.cz/ showtrans.php?cat=clanky\&val=72_aj_clanky.html\&typ=HTML, last accessed on July 6, 2015.

Herder, Johann Gottfried 1778-1779 [1975]. Volkslieder. Available at http://www.zeno. org/Literatur/M/Herder,+Johann+Gottfried/Liedsammlung/Volkslieder, last accessed on March 22, 2016.

Herder, Johann Gottfried 1807. Stimmen der Völker in Liedern. Halle:Verlag von Otto Hendel. Available at https://ia801409.us.archive.org/29/items/stimmendervlker00mlgoog/ stimmendervlker00mlgoog.pdf, last accessed on March 22, 2016.

Kurkela, Vesa \& Rantanen, Saijaleena 2008. Laulava vallankumous. [Singing Revolution.] In: Pertti Haapala \& Olli Löytty \& Melkas Kukku \& Tikka Marko (eds.) Kansa kaikkivaltias: Suurlakko Suomessa. [Almighty Nation: A General Strike in Finland.] Helsinki: Teos, pp. 177-194.

Laugaste, Eduard 1963. Eesti rahvaluuleteaduse ajalugu. [History of the Estonian Folkloristics.] Tallinn: Eesti Riiklik Kirjastus.

M[adisson], J. \& M[addisoo], E[ugen] 1935-1936. Rahvus. In: Richard Kleis (chief ed.) Eesti Entsüklopeedia. [Estonian Encyclopedia.] Tartu: Loodus, p. 1382.

Mänd, Ahti 1995. 1938. a. Põhiseadusele tuginev Eesti Vabariigi Valitsus ehk Nõmme valitsus. [Government of the Republic of Estonia Based on the Constitution of 1938 or Nõmme Government.] http://www.nommevalitsus.org/index.php?option=com content\&view=article\&id=1306\&Itemid=133\&lang=et, last accessed in June 2015 (no longer available).

Meyer, Leo 1896. Acht estnische Volkslieder aus Herders Nachlass und dreizehn aus Wielands Teutschem Merkur (1787) nebst mehreren alten Hochzeitsgedichten in estnischer Sprache. Verhandlungen der Geleherten Estnischen Gesellschaft zu Dorpat, Bd. 16, Hft. 4. Dorpat: Druck von C. Mattiesen, pp. 237-318.

Oinas, Felix 1994. Surematu Kalevipoeg. [Immortal Kalevipoeg.] Tallinn: Keel ja Kirjandus.

Ojamaa, Triinu \& Labi, Kanni 2007. Natsioon, natsionalism ja muusika: Eesti näide. [Nation, Nationalism, and Music: The Case of Estonia.] Akadeemia, No. 11, pp. 2343-2370. 
Penttinen, Yrjö 1947. Sotasanomat: Inkeriläinen kansanruno ja sen kansainvälistä taustaa. [War Messages: Ingrian Folk Song and Its International Background.] Helsinki: Suomalaisen Kirjallisuuden Seura.

Rantanen, Saijaleena 2013. Laulun mahti ja sivistynyt kansalainen. Musiikki ja kansanvalistus Etelä-Pohjanmaalla 1860-luvulta suurlakkoon. [The Power of Song and the Cultured Citizen: Music and Popular Education in Southern Ostrobothnia from the 1860s to the Russian Revolution in 1905.] Studia Musica 52. Available at http://ethesis.siba.fi/files/nbnfife201301111088.pdf, last accessed on July 6, 2015.

Rinne, Harri 2008. Laulev revolutsioon: Eesti rokipõlvkonna ime. [Singing Revolution: Miracle of Estonian Rock Generation.] Tallinn: Varrak.

Ruutsoo, Rein 2002a. Võimu vaimust ja vaimu võimust. [Power of Mind and Mind of Power.] Riigikogu toimetised, No. 5. Available at http://www.riigikogu.ee/rito/ index.php?id=11752\&o, last accessed on July 6, 2015.

Ruutsoo, Rein 2002b. Civil Society and Nation Building in Estonia and the Baltic States: Impact of Traditions on Mobilization and Transition 1986-2000. Historical and Sociological Study. Rovaniemi: University of Lappland.

Smith, Anthony D. 2009. Ethno-Symbolism and Nationalism: A Cultural Approach. London \& New York: Routledge.

Tedre, Ülo 1961. Eesti rahvalauludest K. Marxi albumis. [About Estonian Folksongs in K. Marx's Album.] Keel ja Kirjandus, No. 9, pp. 517-528. Available at http:// www.digar.ee/arhiiv/et/perioodika/110444, last accessed on July 6, 2015.

Tedre, Ülo 1974. Eesti rahvalaulud IV. [Anthology of Estonian Folksongs, Vol. 4.] Tallinn: Eesti Raamat.

Veidemann, Rein 2008. Laulev revolutsioon. [Singing Revolution.] Newspaper Postimees, June 7. Available at http://www.postimees.ee/1804997/laulev-revolutsioon, last accessed on July 6, 2015. 